\title{
Usulan Perbaikan Lintasan Produksi Minyak Herba Sinergi Menggunakan Value Stream Mapping (Studi Kasus: PT Herba Emas Wahidatama)
}

\author{
Reza Trisnani ${ }^{1 *}$, Amanda Sofiana ${ }^{2}$, Tigar Putri Adhiana ${ }^{3}$ \\ ${ }^{1,2,3}$ Teknik Industri, Universitas Jenderal Soedirman, Purwokerto, Indonesia \\ ('reza.trisnani@mhs.unsoed.ac.id)
}

\begin{abstract}
Abstrak - PT HEW merupakan perusahaan manufacture yang bergerak dalam bidang industri obat tradisional dan pangan olahan. Dalam proses produksinya, MHS melalui 3 tahapan proses yaitu pengolahan, pengemasan primer dan pengemasan sekunder. Permasalahan yang terjadi adalah target produksi dari proses pengemasan, baik primer maupun sekunder belum tercapai. Tidak tercapainya target produksi tersebut disebabkan oleh terdapatnya waste yang menyebabkan aktivitas produksi berjalan kurang optimal. Waste yang ditemukan selama observasi awal yaitu unnecessary inventory berupa WIP, defect, unnecessary motion, inappropriate processing, excessive transportation dan waiting time. Penelitian ini menggunakan value stream mapping untuk memetakan seluruh aliran informasi dan material guna mengidentifikasi waste yang ada di dalam proses produksi. Setelah diidentifikasi, akan ada usulan perbaikan untuk mereduksi waste yang ada. Penelitian dimulai dengan pengambilan data waktu menggunakan stopwatch time study. Waktu proses digunakan dalam value stream mapping untuk mengetahui alur proses dan lead time produksi. Penelitian ini menghasilkan usulan perbaikan yang terdiri atas 5 tindakan. Pada future state map menghasilkan production lead time berkurang sebanyak 34.57\%, total cycle time berkurang sebanyak 51.85\%, line efficiency meningkat sebanyak $11.07 \%$ dan aktivitas non value added berkurang sebanyak $61.53 \%$ serta target produksi meningkat menjadi $140 \%$.
\end{abstract}

Kata kunci: lean manufacturing; seven waste; value stream mapping

\section{PENDAHULUAN}

Negara Indonesia termasuk salah satu negara dengan iklim tropis. Potensi tanaman yang digunakan sebagai obat tradisional sangat tinggi seperti jahe, kunyit, temulawak, sambiloto, dan jenis tanaman lainnya. Jamu merupakan obat tradisional yang turun temurun digunakan oleh nenek moyang Indonesia sejak berabad silam sebagai salah satu upaya menjaga kesehatan dan merawat kecantikan. Ketua Perkumpulan Pelaku Jamu Alami Indonesia (PPJAI) Mukit Hendrayatno mengatakan salah satu industri yang mampu bertahan dan bahkan bertumbuh pada saat pandemi adalah jamu tradisional. Berdasarkan data statistik Kemenperin mendokumentasikan pada triwulan I tahun 2020, industri kimia, farmasi, dan obat tradisional berpotensi tumbuh sebesar 5,59 persen dari tahun sebelumnya. Kinerja positif ini diraih di tengah dampak pandemi Covid19, karena industri tersebut termasuk sektor yang masih memiliki permintaan cukup tinggi di pasar. (www.kemenperin.go.id, 2020)

PT Herba Emas Wahidatama yang selanjutnya akan disingkat PT HEW merupakan perusahaan manufacture yang bergerak dalam bidang industri obat tradisional dan pangan olahan. Target produksi PT HEW dalam 1 bulan mencapai 1.342 .400 produk dengan target produksi tertinggi adalah produk Minyak Herba Sinergi (MHS) mencapai 600.000 produk. Selain MHS, PT HEW memproduksi 10 produk lainnya yaitu sari kurma, dates syrup, mustika dara, madu habbat, madu multiflora, madu premium, janna tea cold, janna tea hot, zaitun, dan deep olive. Proses produksi MHS ada 3 tahapan yaitu pengolahan, pengemasan primer, dan pengemasan sekunder. Pengolahan merupakan proses memasak semua bahan dan mixing. Pengemasan primer merupakan proses pengemasan dimana produk bersentuhan langsung dengan kemasannya sedangkan pengemasan sekunder merupakan proses pengemasan diluar kemasan utama seperti pemberian label, plastic, dus/box dan sebagainya. Jumlah stasiun kerja pada lini produksi MHS pada proses pengolahan terdapat 1 stasiun kerja, pada proses pengemasan primer terdapat 6 stasiun kerja dan pada proses pengemasan sekunder terdapat 7 stasiun kerja.

Observasi data dan observasi lapangan dilakukan pada lini produksi pengemasan primer dan pengemasan sekunder. Target produksi WIP (work-in-process) 1 shift di masing-masing proses adalah 1 batch atau sebanyak 29.540 unit produk. Permasalahan yang terjadi pencapaian target produksi pada proses pengemasan primer dan sekunder kurang dari 100\%. Adapun data yang diberikan pada bulan Mei, Juni, dan Juli 2020, ratarata pencapaian target WIP lini produksi pada pengemasan primer sebesar $82.58 \%$ dan pada pengemasan 
sekunder sebesar $61.67 \%$. Kurangnya pencapaian target WIP di proses pengemasan primer berpengaruh ke proses selanjutnya, karena WIP ditransfer ke proses selanjutnya apabila WIP tersebut sudah memenuhi 1 batch. Keterlambatan WIP karena kurangnya pemenuhan batch menyebabkan proses selanjutnya tertunda sehingga lini produksinya menganggur sementara.

Permasalahan yang sudah dijelaskan sebelumnya, mengacu pada adanya waste pada proses produksi. Menurut Hines \& Taylor (2000) waste di klasifikasikan menjadi 7 yaitu defect, overproduction, unnecessary inventory, unnecessary motion, inappropriate processing, excessive transportation, dan waiting time. Konsep yang dapat digunakan dalam meminimasi waste adalah dengan konsep lean manufacturing. Lean menunjukkan situasi saat ini, sumber daya yang tersedia dan available kondisi environment (Dibia et al., 2014) sedangkan lean manufacturing sendiri berfokus pada peningkatan efisiensi operasional, mengurangi biaya, dan mengkonfigurasi ulang proses (Kumar et al., 2018). Lean manufacturing merupakan suatu pendekatan sistematis untuk mengidentifikasi dan mengeliminasi pemborosan (waste) dengan cara memaksimalkan aktivitas yang memberikan nilai tambah melalui serangkaian aktivitas penyempurnaan (improvement) agar value stream dapat berjalan lancar sehingga waktu produksi lebih efisien (Kristina et al., n.d. 2019).

Berdasarkan literature review, diketahui bahwa dengan metode VSM dapat membantu kita mengidentifikasi dan mereduksi waste. Pada penelitian sebelumnya yang menggunakan VSM adalah Kristina (2019) dengan waiting time sebagai fokus masalah yang ingin diselesaikan. Dengan permasalahan yang ada pada objek penelitian penulis yang telah dijelaskan pada paragraf sebelumnya, akan digunakan metode VSM untuk mengidentifikasi aliran informasi dan aliran material serta proses produksi dan mereduksi seven waste yang ditemukan selama observasi. Tujuan dari penelitian ini adalah menganalisis aliran proses dengan membuat peta aliran informasi dan material dalam value stream mapping, dan mengidentifikasi waste yang ada pada proses produksi, membuat usulan perbaikan untuk permasalahan yang ditemukan pada current state VSM yang mengacu pada filosofi lean manufacturing sebagai future state value stream mapping sehingga mengurangi pemborosan-pemborosan yang ada pada proses produksi yang sebenarnya dan menganalisis improvement current state VSM setelah diterapkan usulan perbaikan pada future state VSM.

\section{STUDI LITERATUR}

"Lean" pada awalnya dibuat dan didefinisikan sebagai eliminasi waste (muda) dalam buku "The Machine That Changed the World" oleh Womack, Jones, and Roos (Womack et al.1990). Pengertian dari lean manufacturing sendiri adalah sebuah pendekatan sistematis untuk identifikasi dan mengeliminasi waste (nonvalue added activities) melalui improvement yang berkelanjutan (continues) dengan penerapan aliran produknya sistem tarik dari customer agar kepuasan customer tercapai. Fokus utama dari lean manufacturing sendiri adalah untuk mengeliminasi waste yang merupakan semua pada lintasan produksi yang tidak menambah nilai produk yang dibuat atau yang tidak diperlukan dalam membuat produk tersebut (Womack and Jones 1996; McDonald et al.2000). Lean manufacturing merupakan suatu pendekatan sistematis untuk mengidentifikasi dan mengeliminasi pemborosan (waste) dengan cara memaksimalkan aktivitas yang memberikan nilai tambah melalui serangkaian aktivitas penyempurnaan (improvement) agar value stream dapat berjalan lancar sehingga waktu produksi lebih efisien (Kristina et al., n.d. 2019).

Waste adalah semua aktivitas yang dilakukan tanpa menghasilkan nilai. Untuk mengurangi waste harus dilakukan identifikasi waste apa saja yang berada pada proses produksi. Menurut (Hines \& Taylor, 2000) terdapat 7 jenis waste yaitu overproduction, waste berupa memproduksi produk berlebihan, defect berupa kesalahan pada saat kegiatan produksi, unneccessary Inventory berupa inventory material/WIP/finished goods berlebih yang sebenarnya tidak perlu terjadi, bisa juga dalam bentuk delay informasi produk atau material, inappropriate processing merupakan akibat dari kegiatan produksi yang tidak tepat karena prosedur yang salah, excessive transportation berupa pemborosan waktu, usaha dan biaya akibat dari motion yang berlebihan baik dari man power, informasi, produk maupun material, waiting berupa pendayagunaan waktu yang tidak efisien misalnya berhentinya man power, informasi, material atau produk pada salah satu atau lebih stasiun kerja dalam waktu yang cukup lama, unneccessary motion berupa pendayagunaan waktu yang tidak menambah nilai produk maupun proses.

Salah satu tools lean manufacturing adalah Value Stream Mapping (VSM). Value Stream Mapping atau VSM adalah metode memvisualkan lintasan produksi dari produk yang di dalamnya termasuk aliran material dan informasi dari masing-masing stasiun kerja dan mampu mengidentifikasi waste (Pradana. dkk, 2018). Value stream adalah segala aktivitas (baik value added maupun non value added) yang dilalui material dan 
informasi untuk membuat produk yang melalui 2 aliran utama yaitu aliran produksi dari raw material sampai customer dan rancangan aliran dari konsep ke implementasi. Value stream mapping (VSM) merupakan salah satu tools lean manufacturing yang berfungsi mengidentifikasikan dan mengeliminasi waste (muda) dan sumbernya yang ada dalam sebuah sistem untuk mendukung keberhasilan dalam penerapan lean manufacturing (Anggoro, 2010). Dalam VSM terdapat 2 pemetaan yaitu pemetaan lintasan produksi eksisting yang disebut current state VSM dan pemetaan lintasan produksi hasil usulan perbaikan yang disebut future state VSM.

Singh et al (2010) menggambarkan VSM sebagai alat yang digunakan untuk mengidentifikasi kesenjangan antara keadaan saat ini dan keadaan masa depan dari proses manufaktur dan menyarankan ruang lingkup untuk perbaikan. Chen et al (2010) menerapkan VSM untuk mengurangi waktu proses dan meningkatkan kualitas produk dengan pelatihan silang karyawan mereka. Vinodh et al., (2013) menguji aplikasi praktis VSM dengan 5S untuk mencapai kehalusan camshaft industri manufaktur dengan menghilangkan limbah. Prashar (2014) menunjukkan penerapan pendekatan Lean-Kaizen menggunakan VSM untuk mendesain ulang jalur perakitan produsen mobil. Widodo (2014) meneliti proses produksi baja dengan membandingkan nilai PCE (Process Cycle Efficiency) setelah menemukan waste dan reduksi aktivitas-aktivitas yang menjadi penyebab kurang optimalnya proses produksi. Andrade (2016) menggunakan VSM pada penelitiannya dengan usulan penerapan FIFO (First In First Out) dan operator diberdayakan dengan optimal dengan penerapan sistem operasi bolakbalik operator tunggal. Nallusamy \& Adil Ahamed (2017) menggunakan VSM menemukan beberapa solusi untuk menangani material handling dengan menambahkan konveyor di setiap stasiun kerja dan menerapkan 5s dalam area kerja serta merubah tata letak pabrik. Kristina (2019) menggunakan metode VSM untuk meminimasi waiting time yang ada pada setiap work station dengan penyelesainnya menggunakan juga stopwatch time study.

\section{METODOLOGI}

Metodologi penelitian yang dilakukan sebagai berikut:

1. Menentukan produk atau keluarga produk

Hal pertama yang harus dipahami dalam merancang VSM adalah keluarga produk mana yang akan menjadi focus karena VSM tidak bisa dilakukan langsung terhadap semua produk yang ada. Bila langsung diterapkan semua produk VSM akan sangat kompleks dan membutuhkan waktu lama untuk merancangnya. Pemilihan keluarga produk biasanya didasarkan pada jumlah output per hari, permintaan customer dan frekuensi produksi dalam 1 periode tertentu. (Linus, 2010).

2. Menggambar peta kondisi sekarang (Current State VSM)

Current state VSM merupakan peta dasar dari keseluruhan proses existing dimana semua usulan improvement dapat muncul. Current state map berfungsi agar peneliti dapat benar benar memahami aliran proses dan material dari produk yang telah ditentukan. Berikut ini adalah data yang diperlukan untuk merancang current state VSM antara lain:

a. Data proses produksi, meliputi workstation, jumlah operator, peralatan dan perlengkapan produksi, alur proses, defect rate, set up time, change over time, prosedur pemberian perintah produksi.

b. Jam kerja, shift, overtime, hari libur, break, meeting, dll.

c. Jumlah inventory (raw material, WIP, dan finished goods), safety stock.

d. Data customer, meliputi siapa customer-nya, aktual permintaan dalam hari/minggu/bulan, peramalan permintaan, frekuensi pesanan, prosedur pengiriman, dll.

e. Data supplier, meliputi siapa supplier-nya, cycle pemesanan perusahaan, peramalan pemesanan, pengiriman bahan baku dari supplier, prosedur pemesanan, lead time pemesanan, dll.

f. Sistem production control data, meliputi siapa yang bertugas mengontrol, manual atau automated, dll.

g. Takt time, kecepatan dari value stream sehingga dapat menyeimbangkan dengan demand yang didapat dengan membagi waktu yang tersedia (net available time) dengan jumlah demand pada satu periode tertentu.

h. Cycle time, waktu dari selesainya satu part diproses sampai part berikutnya selesai diproses.

i. Jarak antar proses yang dilalui material, operator, data, dll.

j. Value added time dan non-value added time. 
3. Menggambar peta masa depan (Future State VSM)

Future state VSM merupakan mapping yang sudah diterapkan usulan perbaikan dari permasalahan atau cara mereduksi waste yang ditemukan pada current state VSM.

4. Merancang rencana improvement

Rancangan usulan perbaikan dari improvement yang dilakukan membutuhkan hal seperti future-state VSM dan rencana tahunan value stream. Rancangan usulan perbaikan dimulai dengan melakukan breakdown rencana improvement menjadi beberapa bagian secara detail berikut dengan jadwal kapan diterapkannya. Rencana yang sudah di breakdown ditulis di lembar rencana kerja tahunan lengkap dengan keterangan pencapaian saat sudah diimplementasikan.

\section{HASIL DAN DISKUSI}

\section{A. Analisis Current State VSM}

Current state map diawali dari forecasting data demand customer yang kemudian dibuat menjadi schedule produksi untuk departemen produksi dan purchase requirement untuk departemen purchasing. Supplier kemudian mengirimkan raw material setiap hari sesuai dengan perjanjian yang ditentukan. Raw material dikirimkan ke lantai produksi dilakukan setiap hari pula sesuai dengan schedule produksi. Dalam current state map kita dapat melihat bahwa banyak terdapat WIP material diantara setiap proses. Pada proses pengemasan primer terdapat 3 inventory. Inventory yang pertama adalah inventory curah di dalam jirigen dari proses pengolahan, yang kemudian diterima dan disimpan di ruangan penampungan sementara. WIP curah di dalam jirigen memerlukan ruangan yang cukup luas dimana terdapat 140 jirigen. Inventory yang kedua terdapat di setiap workstation di proses pengemasan primer, yang berbeda-beda jumlahnya di setiap inventory bergantung dengan kapasitas conveyor dan hooper. Inventory ke 3 adalah inventory WIP botol tanpa label, WIP dari proses ini akan dikirim ke proses selanjutnya apabila sudah memenuhi 1 batch produksi. WIP ini sudah dalam bentuk curah di dalam botol yang disusun di dalam keranjang, dengan kapasitas keranjang 211 botol. Workstation penataan keranjang, sering menjadi penyebab berhentinya conveyor ketika menerima sensor bahwa conveyor penuh. Hal tersebut dikarenakan penataan keranjang dilakukan secara manual, dengan conveyor yang pendek yakni 0.5 meter sehingga hanya dapat menampung botol sebanyak 20 pcs. Inventori berikutnya terdapat di masing-masing workstation di proses pengemasan sekunder. Transportation WIP di pengemasan sekunder masih menggunakan manual dimana setiap operator akan mengerjakan kegiatannya sebanyak mungkin di waktu tertentu, kemudian operator setelahnya akan mengambil WIP tersebut untuk dikerjakan di proses selanjutnya. WIP yang menumpuk, diawali oleh workstation labelling yang bekerja lebih dulu kurang lebih 1 jam, sementara workstation berikutnya mempersiapkan peralatannya atau ada yang menganggur. Inventory WIP memenuhi meja kerja sehingga gerak operator kurang leluasa. Inventory terakhir ada di proses pengemasan sekunder, dimana inventory tersebut akan di-transport ke warehouse setelah memenuhi 1 batch. Jumlah finished goods pada akhir produksi ini memerlukan area yang cukup luas ada yang disebut sebagai gudang sementara untuk menangani finished goods yang belum dipindahkan ke warehouse. Inventori ini dapat ada karena line produksinya terputus, maka hasil WIP ini ditumpuk terlebih dahulu sebelum dipindah ke proses selanjutnya. 


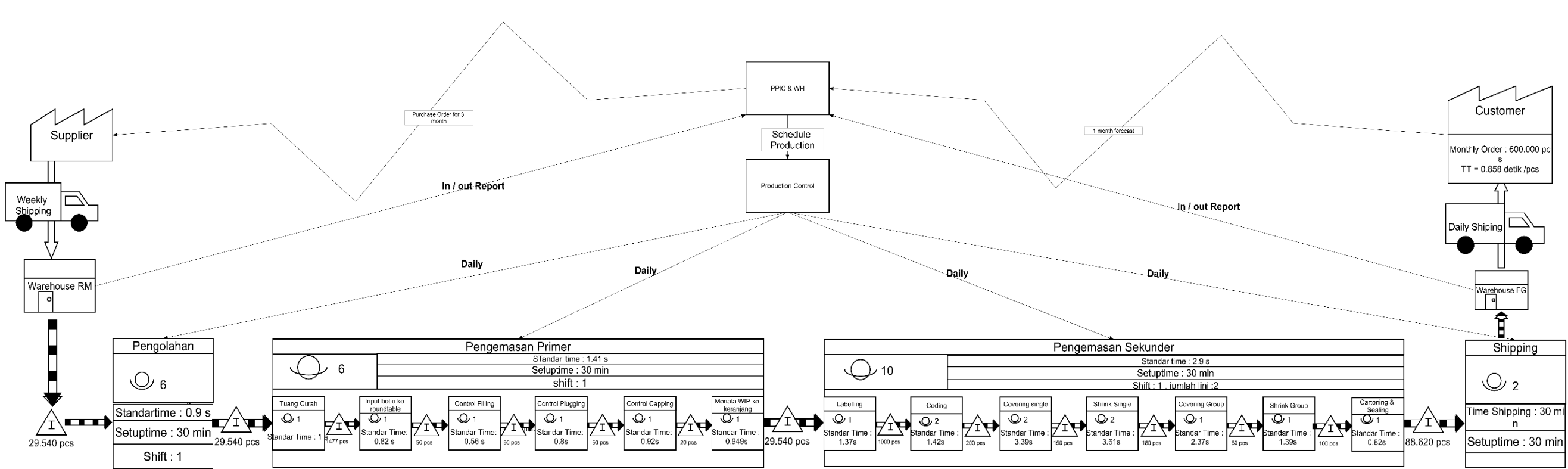

\begin{tabular}{|c|c|c|c|c|c|c|c|c|c|c|c|c|c|c|c|}
\hline & & & & & & & & & & & $2.9 \mathrm{~s}$ & & & & \\
\hline 10 & $1 \mathrm{~d}$ & $0.05 \mathrm{~d}$ & $0.002 \mathrm{~d}$ & $0.002 \mathrm{~d}$ & 0.002 d & $\begin{array}{c}0.0006 \\
d\end{array}$ & $1 \mathrm{~d}$ & $0.034 \mathrm{~d}$ & $\begin{array}{c}0.0067 \\
d\end{array}$ & $0.005 \mathrm{~d}$ & $0.006 \mathrm{~d}$ & $|0.002 \mathrm{~d}|$ & $\begin{array}{c}0.0034 \\
\mathrm{~d}\end{array}$ & $3 d$ & Lead tims: 6,1137 days \\
\hline
\end{tabular}

Gambar 1. Current state mapping 
Tabel 1

Analisis aktivitas produksi MHS

\begin{tabular}{|c|c|c|c|}
\hline Tahapan Proses & Aktivitas & Cycle time (sec) & Keterangan \\
\hline Pengolahan & Mixing dan Memasak & 0.9 & $\mathrm{VA}$ \\
\hline \multirow{10}{*}{ Pengemasan Primer } & Mengambil jirigen & 0.042 & NVA \\
\hline & Tuang Curah ke hooper & 0.93 & NNVA \\
\hline & Memindahkan jirigen kosong & 0.028 & NVA \\
\hline & Unscrambler & 0.82 & NNVA \\
\hline & Filling Bottle & 0.56 & VA \\
\hline & Pluging & 0.8 & VA \\
\hline & Capping & 0.92 & VA \\
\hline & Mengambil keranjang & 0.057 & NVA \\
\hline & Penataan botol ke dalam keranjang & 0.82 & NNVA \\
\hline & Memindahkan keranjang penuh & 0.072 & NVA \\
\hline \multirow{19}{*}{ Pengemasan Sekunder } & Meletakan botol ke roundtable & 0.44 & NNVA \\
\hline & Labelling botol & 0.47 & VA \\
\hline & Memasukkan botol ke keranjang & 0.46 & NNVA \\
\hline & Memindahkan keranjang & 0.06 & NVA \\
\hline & Meletakkan botol ke conveyor & 0.47 & NVA \\
\hline & Coding Label & 0.41 & VA \\
\hline & Memindahkan botol ke meja & 0.48 & NVA \\
\hline & Menggeser botol & 0.22 & NVA \\
\hline & Covering Single Product & 3.17 & VA \\
\hline & Memindahkan botol & 0.31 & NVA \\
\hline & $\begin{array}{l}\text { Shrink Single Product dengan hot } \\
\text { gun }\end{array}$ & 3.3 & VA \\
\hline & Menggeser botol & 0.2 & NVA \\
\hline & Covering Group Product & 2.17 & VA \\
\hline & Memindahkan botol & 0.18 & NVA \\
\hline & $\begin{array}{l}\text { Shrink Group Product dengan hot } \\
\text { gun }\end{array}$ & 1.21 & VA \\
\hline & $\begin{array}{l}\text { Packing Karton Product dan } \\
\text { Penimbangan }\end{array}$ & 0.53 & VA \\
\hline & $\begin{array}{l}\text { Memindahkan karton ke mesin } \\
\text { sealing }\end{array}$ & 0.1 & NVA \\
\hline & Sealing & 0.0513 & VA \\
\hline & Memindahkan karton ke pallet & 0.14 & NVA \\
\hline
\end{tabular}

Setelah dianalisis maka berikut ini adalah rekapitulasi aktivitas berdasarkan jenisnya:

Tabel 2

Rekapitulasi jenis aktivitas VA, NVA, dan NNVA

\begin{tabular}{clccc}
\hline No & Jenis Aktivitas & Jumlah Aktivitas & Time (detik) & $\%$ Time Activity \\
\hline 1 & Value Added & 12 & 14.4913 & 71.07 \\
2 & Non Value Added & 13 & 2.359 & 12.12 \\
3 & Necessary but Non Value Added & 5 & 3.47 & 16.81 \\
\hline \multicolumn{5}{c}{ Total Time } \\
\hline
\end{tabular}


B. Analisis Future State VSM

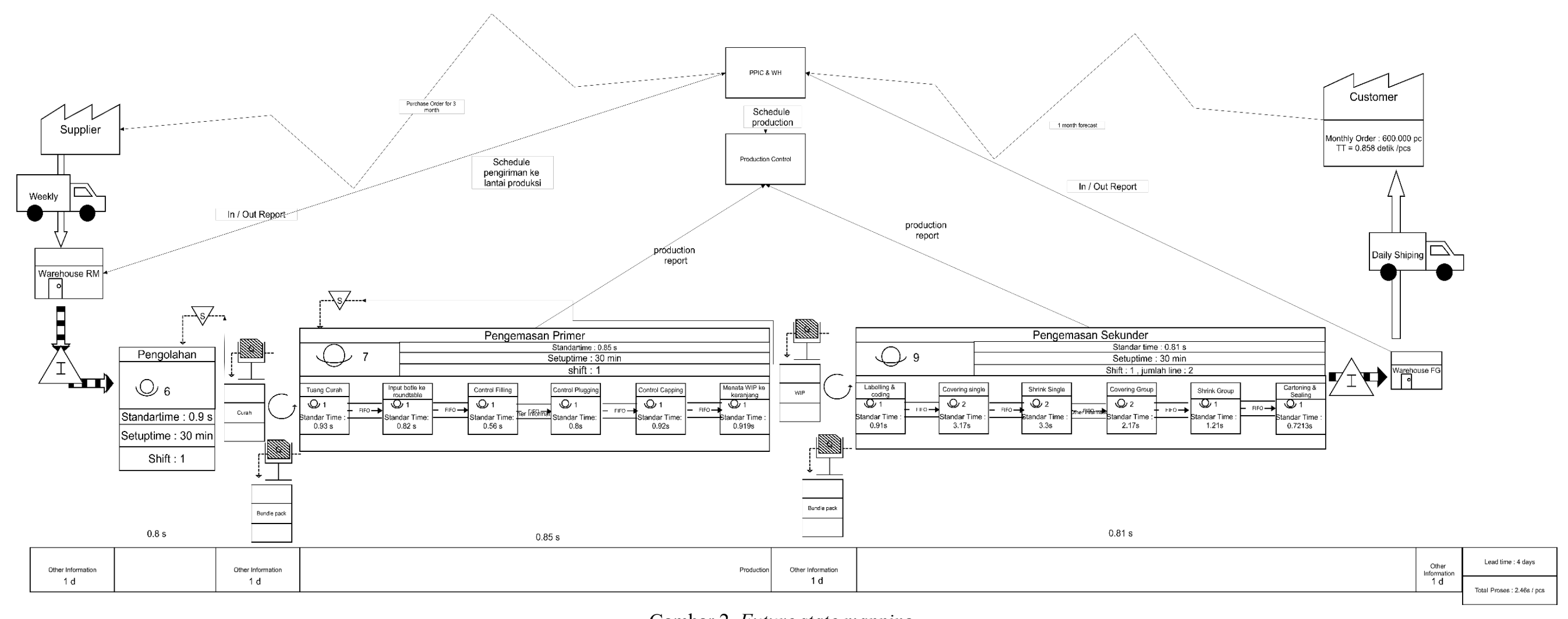

Gambar 2. Future state mapping 


\section{1) Takt Time}

Pada tahap awal pembuatan future state map, telah ditentukan takt time dari produk MHS yaitu 0.858 detik. Pengertian dari takt time sendiri adalah kecepatan dari value stream sehingga dapat menyesuaikan dengan demand dari customer atau dengan kata lain, waktu yang diperlukan untuk memproduksi satu unit produk MHS dari raw material datang sampai produk akhir berada di tangan customer. Oleh karena itu takt time ini dijadikan sebagai cycle time dari pacemaker proses dalam hal ini adalah workstation. Cycle time pada pacemaker proses ini akan berdampak pada workstation-workstation upstream-nya sehingga semuanya harus memiliki cycle time 0.858 detik untuk menyeimbangi aliran pada future value stream map, kecuali pada proses pengemasan sekunder, karena ada 2 lini maka takt timenya adalah 2 x 0.858 detik yakni 1.716 detik.

\section{2) Continuous Flow}

Konsep contiuous flow ini sudah diterapkan di proses pengolahan dan proses pengemasan primer, sehingga pada future state map ini mencoba untuk diterapkan pada pengemasan sekunder. Dalam penerapan continuous flow diperlukan line balancing untuk penyesuaian jumlah operator pada proses pengemasan sekunder. Berdasarkan pengolahan data yang telah dilakukan, maka didapat cycle time untuk line tersebut adalah 1.716 detik untuk 2 lini produksi, sehingga sesuai dengan takt time dan cycle time yang diterapkan pacemaker proses. Logikanya adalah dalam 1.716 detik menghasilkan 2 produk yang artinya per produknya memiliki takt time 0.858 detik. Setiap workstation dan conveyor diatur agar kecepatan dan lama prosesnya mengikuti takt time yang ada. Permasalahan yang muncul dalam penerapan continuous flow ini adalah proses adaptasi dari operator itu sendiri. Pada current state map, cycle time dari masing-masing workstation dalam satu line berbeda-beda dan cukup fluktuatif, kemudian pada future state map dijadikan kurang atau sama dengan takt time. Oleh karena itu diperlukan penyesuaian dari pihak operator maupun mesin. Penyesuaian dari mesin dengan cara melakukan standarisasi setup/konfigurasi mesin agar tidak terjadi downtime. Penyesuaian operator, apabila terjadi kenaikan atau penurunan demand, operator harus dapat menyesuaikan dengan takt time yang berbeda, baik dipercepat maupun diperlambat.

Tabel 3

Rekapitulasi standard time setelah continuous flow

\begin{tabular}{|c|c|c|c|}
\hline Work Station & Aktivitas & Standard time & Jumlah Standard Time \\
\hline Pengolahan & Mixing dan Memasak & 0.9 & 0.9 \\
\hline \multirow{3}{*}{ Penuangan curah ke hooper } & Mengambil jirigen & 0.042 & \multirow{3}{*}{0.93} \\
\hline & Menuangkan Curah ke hooper & 0.86 & \\
\hline & Memindahkan jirigen kosong & 0.028 & \\
\hline Unscrambler & Meletakkan botol ke roundtable & 0.82 & 0.82 \\
\hline Filling bottle & Control Filling Bottle & 0.56 & 0.56 \\
\hline Plugging & $\begin{array}{l}\text { Memasukkan plug ke mesin dan } \\
\text { control plugging }\end{array}$ & 0.8 & 0.8 \\
\hline Capping & $\begin{array}{l}\text { Memasukkan cap ke mesin dan } \\
\text { control caping }\end{array}$ & 0.92 & 0.92 \\
\hline \multirow{3}{*}{ Penataan botol ke keranjang } & Mengambil keranjang & 0.057 & \multirow{3}{*}{0.919} \\
\hline & Penataan botol ke dalam keranjang & 0.82 & \\
\hline & Memindahkan keranjang & 0.072 & \\
\hline \multirow{2}{*}{ Labelling bottle } & Meletakan botol ke roundtable & 0.44 & \multirow{2}{*}{0.91} \\
\hline & Labelling botol & 0.47 & \\
\hline Coding label & Coding Label & 3.17 & 3.17 \\
\hline Covering Single Product & Covering Single Product & 3.3 & 3.3 \\
\hline Shrink Single Product & $\begin{array}{l}\text { Shrink Single Product dengan hot } \\
\text { gun }\end{array}$ & 2.17 & 2.17 \\
\hline Covering Group Product & Covering Group Product & 1.21 & 1.21 \\
\hline Shrink Group Product & $\begin{array}{l}\text { Shrink Group Product dengan hot } \\
\text { gun }\end{array}$ & 0.9 & 0.9 \\
\hline \multirow{4}{*}{ Packing karton \& sealing } & $\begin{array}{l}\text { Packing Karton Product dan } \\
\text { Penimbangan }\end{array}$ & 0.53 & \multirow{3}{*}{0.7213} \\
\hline & Sealing & 0.0513 & \\
\hline & Memindahkan karton ke pallet & 0.14 & \\
\hline & Total Standard Time & & 17.3603 \\
\hline
\end{tabular}


3) Supermarket

Ketiga proses produksi MHS yakni pengolahan, pengemasan primer dan pengemasan sekunder tidak memungkinkan untuk dijadikan dalam satu line produksi, maka dibuat supermarket sebagai pengontrol produksi antara proses downstream dengan upstream-nya. Namun, supermarket tidak bisa diterapkan di semua tempat. Pada hal ini, supermarket diterapkan di pengemasan primer dan pengemasan sekunder. Selain sebagai pengontrol proses produksi, supermarket ini juga dapat berfungsi sebagai safety stock. Safety stock pada supermarket ini dibutuhkan untuk mengantisipasi terjadinya breakdown mesin dan kekurangan WIP akibat ada kendala di proses sebelumnya atau ada kendala raw material yang datang tidak tepat waktu. Jumlah dari safety stock pada supermarket ini ditentukan berdasarkan kapasitas produksi 1 hari yaitu 1 batch. Sedangkan lot size yang ditetapkan adalah 1 palet untuk memudahkan material handling.

4) Perubahan Jumlah Operator dengan Metode Line Balancing

Tabel 4

Konfigurasi perubahan jumlah operator lini pengemasan sekunder

\begin{tabular}{|c|c|c|c|c|c|}
\hline Workstation & Proses & $\begin{array}{c}\mathrm{ST} \\
\text { (detik/unit) }\end{array}$ & $\begin{array}{c}\mathrm{ST} / \mathrm{TT} \\
\text { (operator) }\end{array}$ & $\begin{array}{l}\text { Jumlah } \\
\text { Operator }\end{array}$ & $\begin{array}{l}\text { Waktu per orang } \\
\text { (detik per unit) }\end{array}$ \\
\hline 1 & $\begin{array}{l}\text { Labelling Botol dan Coding } \\
\text { label }\end{array}$ & 0.91 & 0.49 & 1.00 & 0.91 \\
\hline 2 & Covering Single Product & 3.17 & 1.72 & 2.00 & 1.59 \\
\hline 3 & $\begin{array}{l}\text { Shrink Single Produk dengan } \\
\text { Hot Gun }\end{array}$ & 3.30 & 1.79 & 2.00 & 1.65 \\
\hline 4 & Covering Group Produk & 2.17 & 1.17 & 2.00 & 1.09 \\
\hline 5 & $\begin{array}{l}\text { Shrink Group Produk dengan } \\
\text { Hot Gun }\end{array}$ & 1.21 & 0.65 & 1.00 & 1.21 \\
\hline 6 & $\begin{array}{l}\text { Packing Karton Product dan } \\
\text { Penimbangan }\end{array}$ & 0.72 & 0.39 & 1.00 & 0.72 \\
\hline & Total & 11.48 & 6.21 & 9.00 & 7.16 \\
\hline
\end{tabular}

Dengan penerapan continuous flow pada proses pengemasan sekunder maka dilakukan perhitungan ulang jumlah operator optimal di setiap workstation dengan metode line balancing. Perubahan pertama pada workstation labelling dan coding yang digabung menjadi 1 workstation dengan jumlah operator 1 . Kemudian pada workstation covering group yang awalnya 1 operator menjadi 2 operator. Perubahan jumlah operator tersebut berpengaruh terhadap line efficiency, dimana line efficiency merupakan tolak ukur keefisienan suatu lini produksi dengan cara menghitung jumlah seluruh standart time dibagi dengan standar time terbesar di kalikan standar time terbesar di suatu lini. Semakin besar line efficiency maka semakin baik atau semakin efisien lini tersebut. Rumus (1) berikut ini adalah rumus perhitungan line efficiency:

Tabel 5

Perbandingan Standar Time

\begin{tabular}{ccccccccc}
\hline Kondisi & SK 1 & SK2 & SK 3 & SK 4 & SK 5 & SK 6 & SK 7 & S ST \\
\hline ST sebelum perubahan $(\mathrm{sec})$ & 1.37 & 0.71 & 1.695 & 1.805 & 2.37 & 1.39 & 0.8213 & 10.1613 \\
\hline ST setelah perubahan $(\mathrm{sec})$ & 0.91 & 1.59 & 1.65 & 1.09 & 1.21 & 0.72 & 7.16 \\
\hline
\end{tabular}

Line Efficiency $=(($ jumlah standard time $)) /($ jumlah stasiun kerja $\mathrm{x}$ standard time max $) \times 100 \%$

Sehingga hasil perhitungannya:

Line Efficiency sebelum perubahan $=\frac{10.1613}{7 \times 2.37} \times 100 \%=61.25 \%$

Line Efficiency setelah perubahan $=\frac{7.16}{6 \times 1.65} \times 100 \%=72.32 \%$

\section{Perbandingan Current State VSM dan Future State VSM}

Setelah membuat current value stream map dan future value stream map kita dapat melihat dan menganalisa perbedaan yang tampak dari kedua peta ini. 
Tabel 6

\begin{tabular}{|c|c|c|c|c|}
\hline & $\begin{array}{c}\text { PLT } \\
\text { (Production Lead Time) }\end{array}$ & $\begin{array}{c}\text { TCT } \\
\text { (Total Cycle Time) } \\
\end{array}$ & $\begin{array}{c}\mathrm{LE} \\
\text { (Line Efficiency) }\end{array}$ & $\begin{array}{c}\text { Jumlah NVA } \\
\text { (aktivitas) }\end{array}$ \\
\hline Current State Map & 6.1137 hari & 5.11 detik & $61.25 \%$ & 13 \\
\hline Future State Map & 4 hari & 2.46 detik & $72.32 \%$ & 5 \\
\hline Selisih & 2.1137 hari & 2.65 detik & $11.07 \%$ & 8 \\
\hline
\end{tabular}

\section{KESIMPULAN}

Berdasarkan penelitian pada sistem produksi di PT HEW di proses produksi produk MHS yaitu dalam current state map proses produksi didapatkan beberapa waste yang tidak sesuai dengan konsep lean manufacturing yaitu unnecessary inventory berupa WIP, defect, unnecessary motion, inappropriate processing, excessive transportation, dan waiting time. Kemudian untuk usulan perbaikan mengatasi waste sesuai dengan hasil analisa current state maping meliputi penerapan Continues Flow pada proses pengemasan sekunder, melakukan standarisasi konfigurasi setup mesin pada proses pengemasan primer, mengadakan pelatihan SDM untuk peningkatan kualitas SDM, mengalokasikan operator dari stasiun kerja coding label ke covering group product dan menyatukan stasiun kerja labelling bottle dan coding label, penambahan panjang conveyor di stasiun kerja penataan botol ke dalam keranjang pada proses pengemasan primer dan memindahkan stasiun kerja ke ruang sebelah. Improvement yang diperoleh dari future state map yang telah dibuat meliputi production lead time berkurang sebanyak $34.57 \%$, total cycle time berkurang sebanyak $51.85 \%$, line efficiency meningkat sebanyak $10.07 \%$ dan aktivitas non value added berkurang sebanyak $61.53 \%$. Dengan pengaturan tersebut target produksi mampu meningkat sebesar $140 \%$. Saran untuk penelitian selanjutnya adalah melakukan simulasi current state mapping dan future state mapping untuk mengetahui lebih detail lagi mengenai output produksi dari usulan perbaikan dalam sistem nyata sehingga lebih optimal.

\section{DAFTAR PUSTAKA}

Andrade, P. F., Pereira, V. G., \& Del Conte, E. G. (2016). Value stream mapping and lean simulation: a case study in automotive company. International Journal of Advanced Manufacturing Technology, 85(1-4), 547-555. https://doi.org/10.1007/s00170-015-7972-7

Anggoro, D. D. (2010). Usulan Perbaikan \& Reduksi Terhadap Stream Mapping Pada Lintasan Produksi.

Chen, J. C., Li, Y., \& Shady, B. D. (2010). From value stream mapping toward a lean/sigma continuous improvement process: An industrial case study. International Journal of Production Research, 48(4), 1069-1086. https://doi.org/10.1080/00207540802484911

Dibia, I. K., Dhakal, H. N., \& Onuh, S. (2014). Lean "leadership People Process Outcome" (LPPO) implementation model. Journal of Manufacturing Technology Management, 25(5), 694-711. https://doi.org/10.1108/JMTM-08-2011-0076

Hines, P. \& Taylor, D., (2000), Going Lean, Cardiff, Lean Enterprise Research Centre Cardiff Business School, UK

Kristina, J., dkk. 2019. MINIMASI WAITING TIME DENGAN PENDEKATAN VALUE STREAM MAPPING DAN SIMULASI PADA PRODUKSI RUMAH POTONG AYAM WAITING TIME MINIMIZATION WITH VALUE STREAM MAPPING APPROACH AND SIMULATION ON CHICKEN SLAUGHTERHOUSE PRODUCTIO. TEKNIK INDUSTRI UNIVERSITAS BRAWIJAYA 7(4), 45-55.

Kumar, S., Dhingra, A. K., \& Singh, B. (2018). Cost reduction by value stream mapping using Lean-Kaizen concept: a case study. International Journal of Productivity and Quality Management, 24(1), 12-32. https://doi.org/10.1504/IJPQM.2018.091166

Linus, B. (2010). PERANCANGAN LEAN PRODUCTION SYSTEM DENGAN PENDEKATAN VALUE STREAM MAPPING DAN PERMODELAN SISTEM: STUDI KASUS PADA SISTEM PRODUKSI 
STAMPING DAN WELDING SKRIPSI Diajukan sebagai salah satu syarat untuk memperoleh gelar sarjana teknik UNIVERSITAS INDONESIA .

McDonald, T.; E. Van Aken; and R. Butler. 2000. "Integration of Simulation and Value Stream Mapping in Transformation toLean Production", IIE Annual Conference.

Nallusamy, S., \& Adil Ahamed, M. A. (2017). Implementation of lean tools in an automotive industry for productivity enhancement - A case study. International Journal of Engineering Research in Africa, 29(March), 175-185. https://doi.org/10.4028/www.scientific.net/JERA.29.175

Pradana. dkk. (2018). IMPLEMENTASI KONSEP LEAN MANUFACTURING pekerjaan atau tugas dari mulai perancangan sampai dengan produk diterima konsumen agar dapat berjalan lancar dan tidak mengalami pemberhentian atau pengembalian yang disebabkan karena cacat atau waste ( Muhsin dkk,. Jurnal Optimasi Sistem Industri, 11(1), 14-18.

Prashar, A. (2014). Redesigning an assembly line through Lean-Kaizen: An Indian case. TQM Journal, 26(5), 475-498. https://doi.org/10.1108/TQM-04-2013-0054

Singh, B., Garg, S. K., Sharma, S. K., \& Grewal, C. (2010). Lean implementation and its benefits to production industry. International Journal of Lean Six Sigma, 1(2), 157-168. https://doi.org/10.1108/20401461011049520

Vinodh, S., Somanaathan, M., \& Arvind, K. R. (2013). Development of value stream map for achieving leanness in a manufacturing organization. Journal of Engineering, Design and Technology, 11(2), 129141. https://doi.org/10.1108/JEDT-01-2010-0007

Widodo, E. J., Herlina, L., \& Febianti, E. (n.d.). Analisis Proses Produksi HRPO Menggunakan Metode Lean Manufacturing Dengan Pendekatan Simulasi Di Divisi Cold Rolling Mill ( Studi Kasus di PT . KS ).

Womack, J.; D. Jones; and D. Roos. 1990. The Machine that Changed the World - The History of Lean Production, Harper Perennial, New York.

Womack, J. and D. Jones. 1996. Lean Thinking - Banish Waste and Create Wealth in your Corporation, Simon \& Schuster, New York.

www.kemenperin.go.id. (2020). Kemenperin Dorong Peningkatan TKDN Produk Farmasi. https://www.kemenperin.go.id/artikel/21812/Kemenperin-Dorong-Peningkatan-TKDN-Produk-Farmasi 